\title{
Landslides and other damage to buildings and infrastructures following the April-May 2015 earthquake sequence, Solukhumbu District, Eastern Nepal
}

\author{
*Monique Fort1,4, Joëlle Smadja2,4, Narendra Raj Khanal3,4, and Buddhi Raj Shrestha ${ }^{3,4}$ \\ ${ }^{1}$ Université Paris Diderot, GHES, Case 7001, UMR 8586 PRODIG CNRS, Paris Cedex 13, France \\ ${ }^{2}$ Centre for Himalayan Studies, UPR 299. CNRS, 7 rue Guy Môquet, 94800 Villejuif, France \\ ${ }^{3}$ Geography Department, Tribhuvan University, Kirtipur, Kathmandu, Nepal \\ ${ }^{4}$ ANR-13-SENV-0005-02 PRESHINE \\ *Corresponding author: fort@univ-paris-diderot.fr
}

\begin{abstract}
The study focuses on the eastern margin of the zone affected by the April-May 2015 earthquakes, i.e. the Dudh Koshi River section between the Khari Khola and Monjo (Solukhumbu District). Visits before and after the earthquake sequence allowed us to assess the geomorphic changes caused by the earthquakes and the subsequent monsoon. These changes are characterised by landsliding (rock falls, rockslides, landslides, gullies and debris flows), and cascading processes, which supplied coarse debris into rivers (bedload). The impact of the earthquakes on buildings, trails and existing infrastructures (canals, hydropower plants) was also investigated. While the age and construction quality of buildings are of some import, other parameters such as the nature and depth of colluvial deposits appear to be significant factors likely to amplify the effects of ground shaking, as observed on large block fields south-west of the Khari Khola catchment, which might be inherited from former undated seismic events.
\end{abstract}

Keywords: Khari Khola, Dudh Koshi, April-May 2015 Earthquake, Landslides, Solukhumbu District

Paper Received: 29 Mar 2019

Paper Accepted: 1 Jun 2019

\section{INTRODUCTION}

The unpredictability and low frequency of major earthquakes make recognition of their role in triggering slope instability difficult to evaluate. The earthquakes $\left(\mathrm{M}_{\mathrm{w}} 7.8\right.$ and $M_{w}$ 7.3) that struck Nepal during the April-May 2015 period provide an exceptional opportunity to assess their role and to specify the type, size and site of disruptions. A large number of landslides were reported and described in the areas between Gorkha and the Sun Koshi valley (Collins and Jibson, 2015; Kargel et al., 2015; Gnyawali et al., 2016; Cook et al., 2016; Shrestha et al., 2016; Roback et al., 2018). By contrast, this study focuses on the eastern margin of the zone affected by the earthquakes, i.e. the Upper Solukhumbu area, along the Dudh Koshi section between the Khari Khola and Monjo, which received only a little attention. Even if the density of landsides is not comparable with observations in central Nepal, it appears that the impact of the earthquakes on both geomorphic processes and infrastructures were significant in this area which is characterised by a tourism-based economy.

We had the opportunity of visiting the Solukhumbu area in spring 2015, just a few weeks prior to the April-May 2015 seismic "Gorkha sequence", and then in November 2015 and once again, during spring 2016. It was therefore possible to make an evaluation of the geomorphic changes and damage to buildings and infrastructures, before and after the earthquakes, as well as of the impacts of the subsequent 2015 monsoon.

\section{STUDY AREA}

The study area (Fig. 1), from Kharikhola up to Monjo, characterised by contrasted monsoon seasonality (Smadja et al., 2015), straddles the Main Central Thrust (MCT) zone and includes both the lower part of the Higher Himalayan Crystallines and the upper part of the Lesser Himalayan meta-sediments (Yoshida et al., 2011; Fig. 2). Gorge sections (quartzites, paragneisses) alternate with wider sections, often corresponding to very large rockslide deposits, as observed at NamcheKhumjung, and between Phakding and Lukla (Heuberger 1986; Weidinger et al., 2014; Goetz et al., 2015) and close to Kharikhola settlement (Fort et al., 2017). A few relicts of glaciations (morainic deposits) exist, as suggested by earlier work (Heuberger and Weingartner, 1985; Owen et al., 2000; Fort 2004). However, massive heterogeneous rockslide deposits, still undated, produced upstream river valley damming, hence controlling the nature of valley fills, such as lacustrine deposits (Ghat) and associated prograding gravel deposits (Chuserma). All these late Quaternary formations were later dissected, hence forming stepped gravelly sandy river terraces and debris fans (Goetz et al., 2015; Posch et al., 2015). Such large mass wasting material and its related deposits are estimated to represent volumes of $>10^{8} \mathrm{~m}^{3}$ covering an area of c. $5.5 \mathrm{~km}^{2}$ (Goetz et al., 2015), with a particularly marked thickness (>150-300 m) close to Ghat and Cheplung (Fig. 3). All together, these Quaternary deposits form a significant part of the geology of the area and introduce high contrasts in material resistance to slope instabilities that could have been 


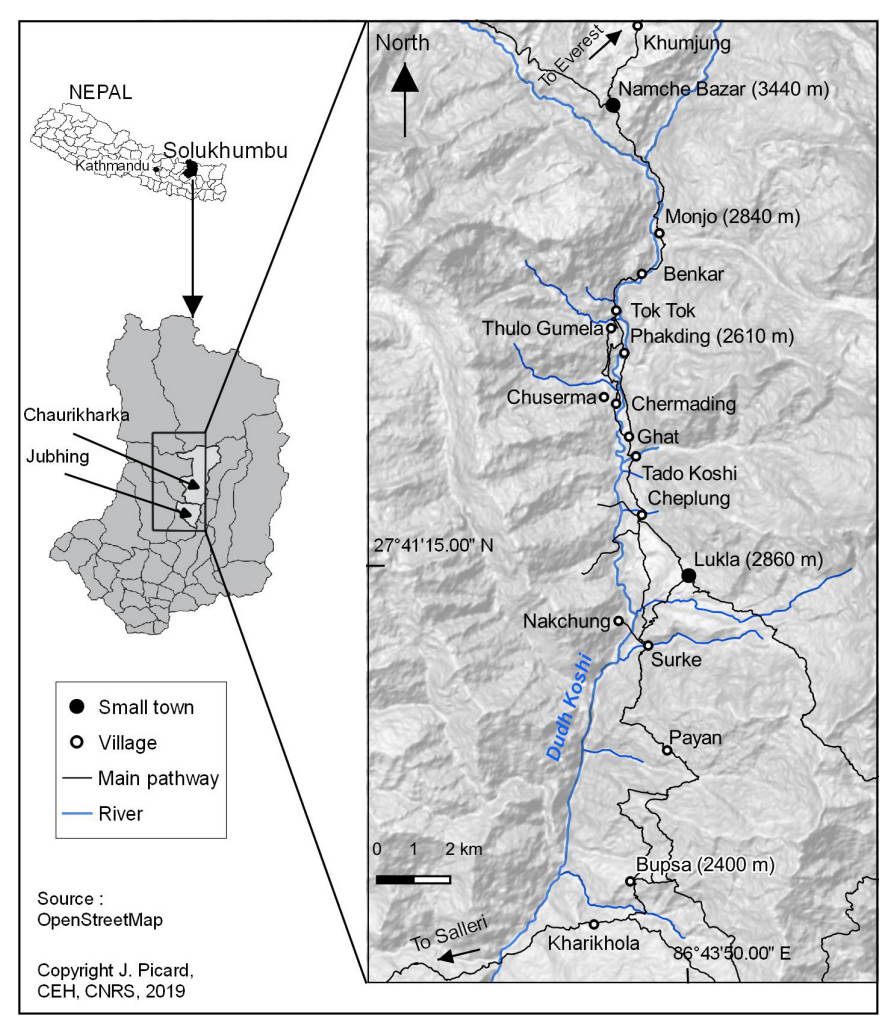

Fig. 1: Location map of the study area, part of Chaurikharka and Jhubing VDC (Solukhumbu district)

induced either by monsoon rainfall or by earthquake shaking.

\section{METHODS}

Three visits to these areas in March 2015, November 2015 and April 2016 allowed us to compare the geomorphic changes (mountain slopes, riverbeds) and damage to buildings and infrastructures, before and after the earthquakes. We surveyed and mapped new earthquake-induced slope instabilities such as rock falls, rockslides, landslides, gullies and debris flows, or a combination of them, and partially cross-checked our inventory using satellite images for the three given periods. More specifically, interviews of inhabitants and surveys of their houses $(n=150)$ helped to specify when exactly the damage to them or landslides had occurred.

\section{RESULTS}

Here we illustrate (i) a few examples of landslides based on the direct comparison (on the field) of some specific sites between March 2015 and November 2015. (ii) We also highlight the cascading processes generated by both the seismic sequence then monsoon rainfall, locally showing good connectivity from the slopes down to the riverbed. (iii) Finally, damage to infrastructures appears to be closely related to the characteristics of slope/ground material.

\section{Landslides}

Even though the density of landsides triggered by the 2015 Gorkha earthquake sequence is not comparable in Solukhumbu with observations in central Nepal, landslide types appear to be rather similar: they are shallow, very superficial, and start at the ridgetop and/or from convex spurs that interrupt hill slopes. Despite local reworking of these by the subsequent monsoon, their initial triggering by the earthquake was confirmed by local interviews. Here we illustrate three representative sites of the different situations we observed.

Among them, the Nakchung village site appears to be most significant. The observed landslides did not exist seven weeks prior to the earthquake sequence, which triggered two types of landslides: rock falls and debris slides (Fig. 4). According to villagers, the slopes were first destabilised during the 25 th April earthquake, but major collapse occurred after the main 12th May aftershock. Two rock falls originated from a paragneissic ridge $\left(35-40^{\circ} \mathrm{N} \mathrm{dip}\right)$, north of the village, along the steep $50^{\circ}$ slope above the Dudh Koshi River. Details of the scarp reveal bedrock dip and orthogonal fractures (Fig. 5) that had been extended in the past by weathering, causing loose blocks to fall down. Two rock fall tracks $(350 \mathrm{~m}$ long for the northernmost one) run across the main trail from Lukla to Nakchung down to the river, isolating villagers from the main valley; they had to be flown to Lukla where they stayed for three months while the trail was being repaired. Yet this trail is no longer safe: in addition to rock falls, debris slides affected the edges of Nakchung cultivated terraces, which lie upon loose, alluvial material superposed on old rockslide deposits (Fig. 4). In fact, most of the new debris slides collapsed at the same sites as those previously affected by bank erosion which had been generated by the 1985 DigTsho GLOF event (Vuichard and Zimmermann 1987).

The second example corresponds to the section along the Dudh Koshi valley between Ghat and Phakding. The right bank, between Chuserma and Chermading, was affected by two slope collapses that occurred after the 12th May earthquake. They appeared to be quite dramatic as the forest was clearly affected (Fig. 6). Yet they correspond to a rather superficial (about $1 \mathrm{~m}$ thick) remobilisation of loose, Quaternary material, as attested to by two large boulders visible before and after the earthquakes. The comparison with the pre-earthquake landscape suggests that both collapses pre-existed. The same is true along the left bank between Chutawa and Ghat, where the collapse of banks affected lacustrine deposits (as a result of the valley dam by the large undated Thadokoshi rockslide) (Fig. 7). Once again, the collapse of all these banks occurred exactly at the same sites as those initiated by the 1985 GLOF (Vuichard and Zimmermann, 1987). They were later stabilised and revegetated, before being reactivated by the 12th May 2015 earthquake. As reported by Utra Bahadur Rai (Ghat), "Earthquake shaking likely initiated additional movement along or across pre-existing fractures, and this deformation progressed gradually in the days following the earthquake until failure occurred on May 22" (quoted by Shrestha, 2017). 


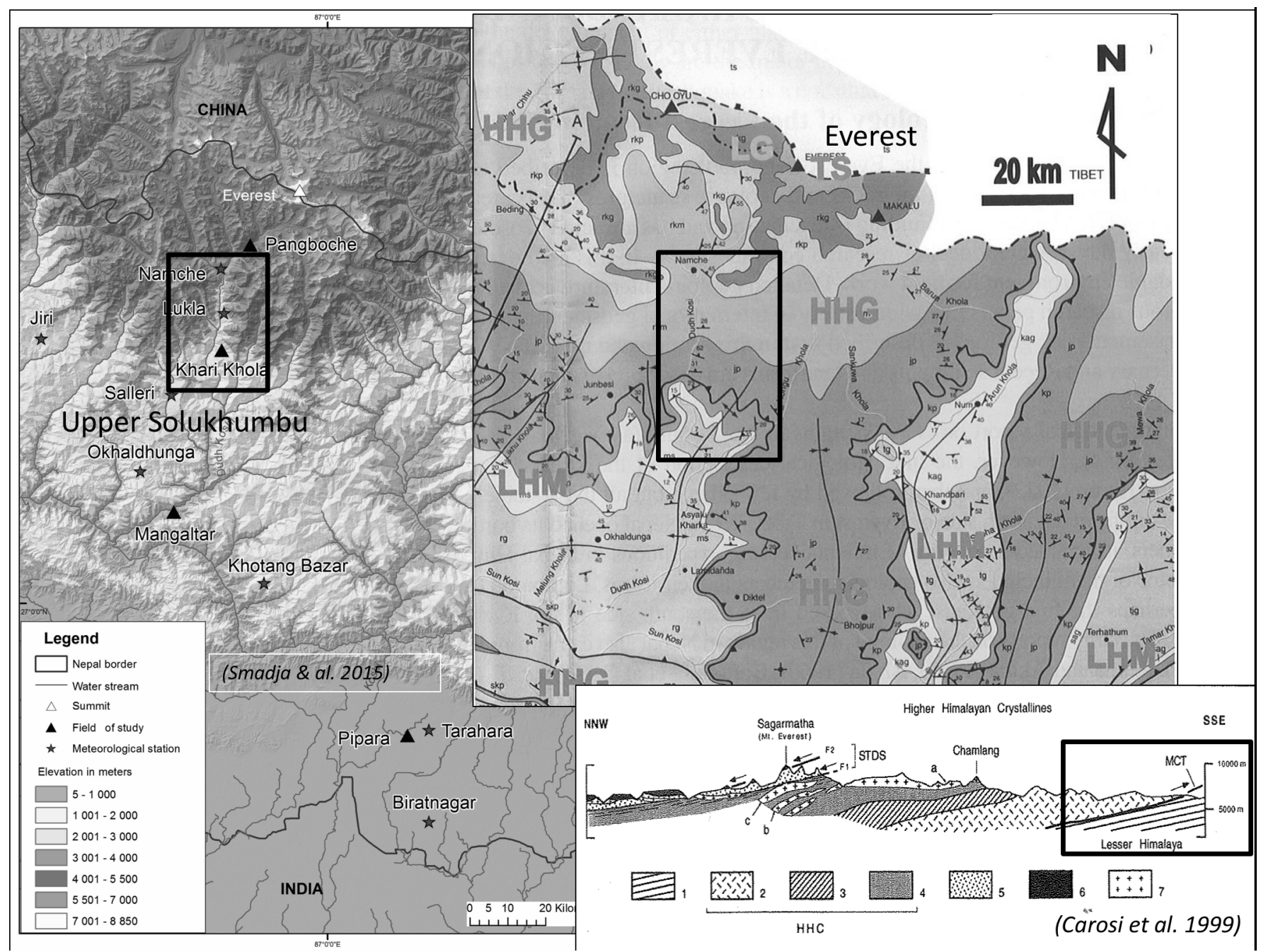

Fig. 2: Topographic map (O. Puschiasis, in Smadja et al. 2015), Geological map (Schelling, 1999, Yoshida et al., 2011), and cross section (Carosi et al., 1999) of Solukhumbu District, with the study area in rectangles.

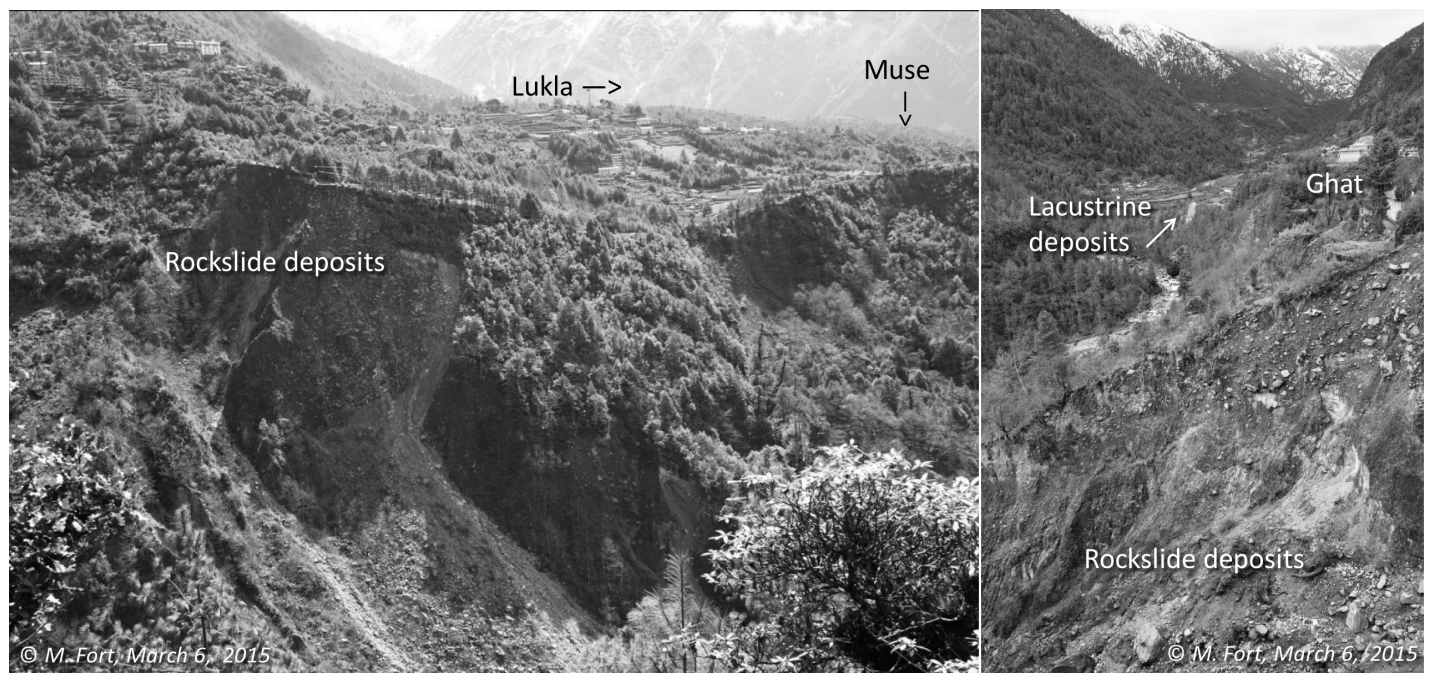

Fig. 3: Examples of legacies of large prehistoric landslides and rockslides, as observed near Ghat-Thado Khosi (left) and Cheplung (right). Note the unsorted, matrix-rich coarse deposits, superficially reworked by slope deposits (colluvium) or fluvial (alluvial) deposits. In some cases, like below Ghat, the volume of landslide material was large enough to dam the valley, which gradually created a landslide-dammed lake, as attested to by lacustrine deposits (Photos: (C) M. Fort). 

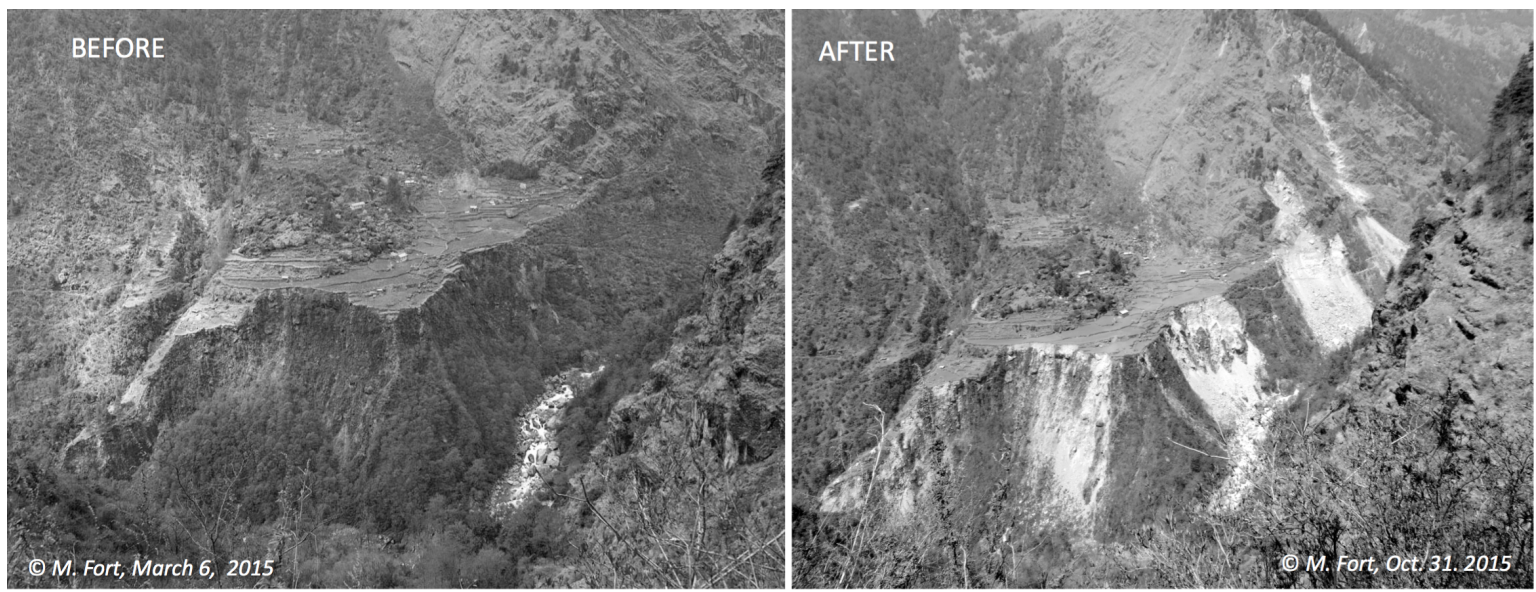

Fig. 4: Nakchung terrace, Solukhumbu, before and after the earthquake. The site of the village corresponds to a terrace partly cut into the Lukla rockslide and filled in with Dudh Koshi River gravel. The surface of the terrace is partly covered by a massive rockfall cone, whereas the edges of the terrace are rather sharp. Recent earthquake-triggered landslides destroyed the vegetation, and reactivated collapses initiated by the 1985 Digh Tsho GLOF. (C) M. Fort, March 2015 and Oct. 2015)

At the third site, south of Monjo (left bank, Dudh Koshi River valley), the terrace cliff, made of coarse torrential, mudsupported alluvial deposits from the Monjo tributary, was "cleaned off" by the earthquake. However, the collapse represents a thickness of less than one metre, as shown by the outcropping of large blocks before and after 12th May 2015. Yet on the top of Monjo terrace, the formation of cracks $(<2 \mathrm{~m}$ from the vertical section) favoured further collapse during the 2015 monsoon.
Role of the 2015 monsoon in promoting cascading processes

During the 2015 monsoon (not a very strong one), earthquake-triggered landslide material was in many places remobilised by a series of cascading processes such as gullying, limited landslide, and runoff, hence favouring the formation of either debris cones or fans at the junction with the main river.

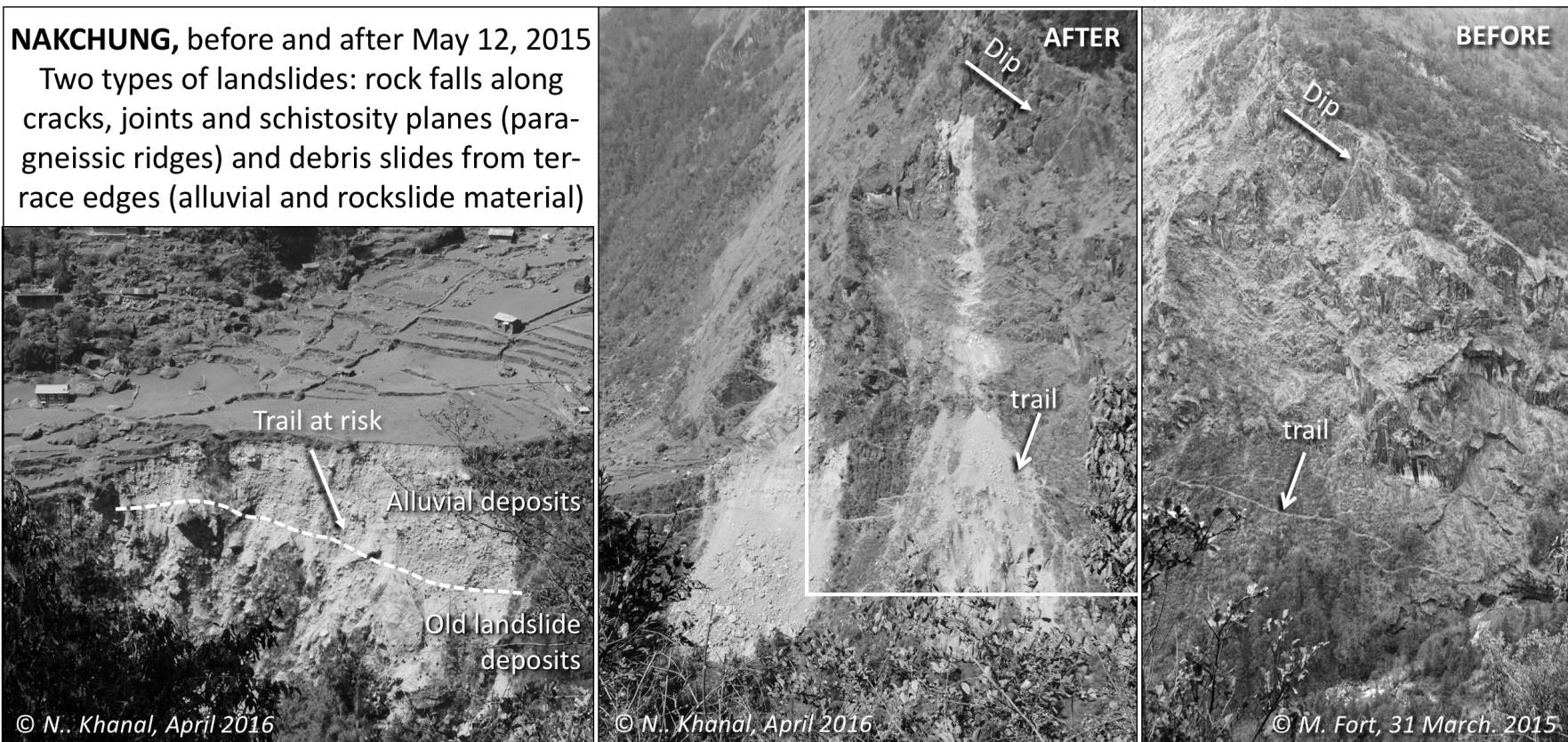

Fig. 5: Two types of landslides affected Nakchung village and its main trail. Rockfalls developed along cracks, joints and schistosity planes (paragneissic ridges) whereas debris slides affected terrace edges (rockslide material topped by alluvial gravels). (@ M. Fort, March 2015, and N.R. Khanal, April 2016). 


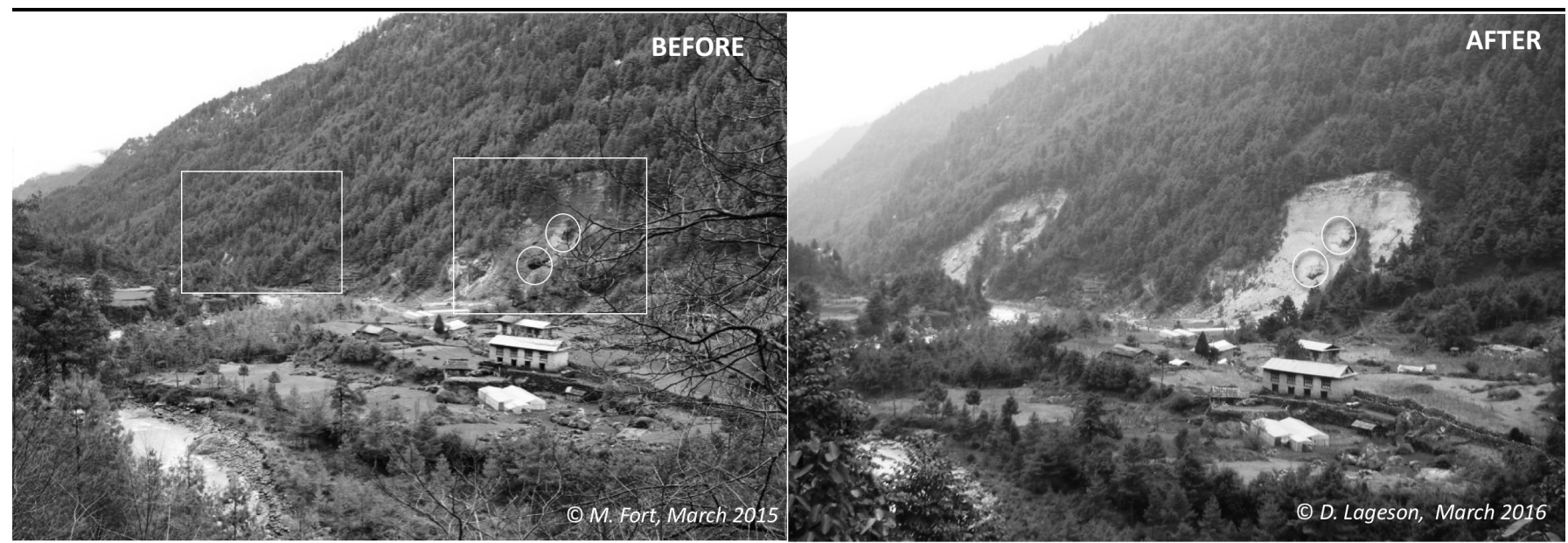

Fig. 6: Lower slope collapses along the Dudh Koshi valley, between Chuserma and Chermading (right bank, opposite Chutawa-Ghat): comparison of landscapes before and after the 2015 earthquake sequence. Note in both cases the large boulders (circles) attesting to the limited thickness of collapse. (Photos: (c) M. Fort, 2015, D. Lageson, 2016).
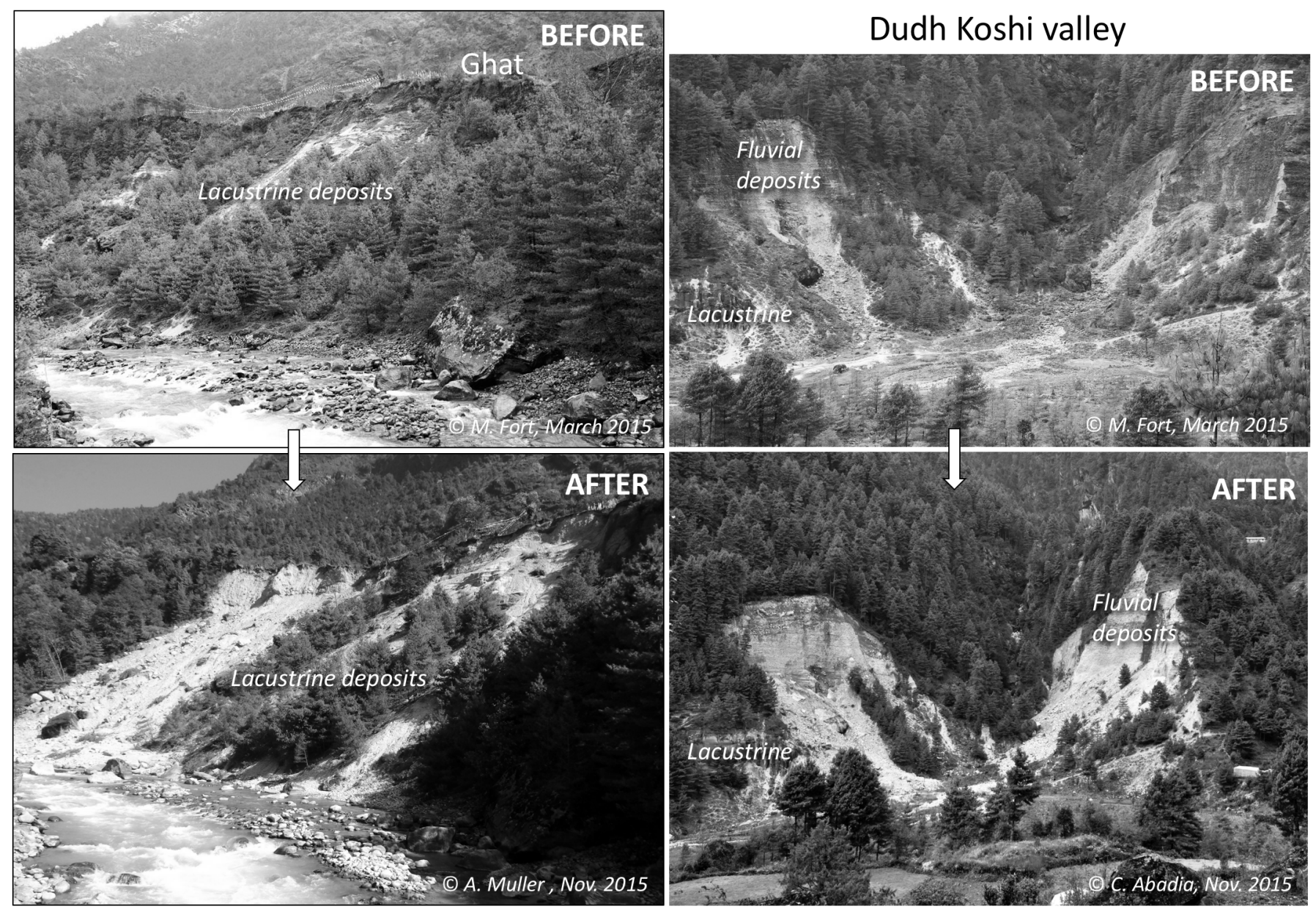

Fig. 7: Slope collapse affecting loose, lacustrine and alluvial deposits along the Dudh Koshi valley near Ghat (left photographs: left bank Ghat, right photos: right bank Chermading). The vegetation is the most damaged, with limited volumes of displaced material. (Photos: () M. Fort, 2015, A. Muller and C. Obadia, 2015) 


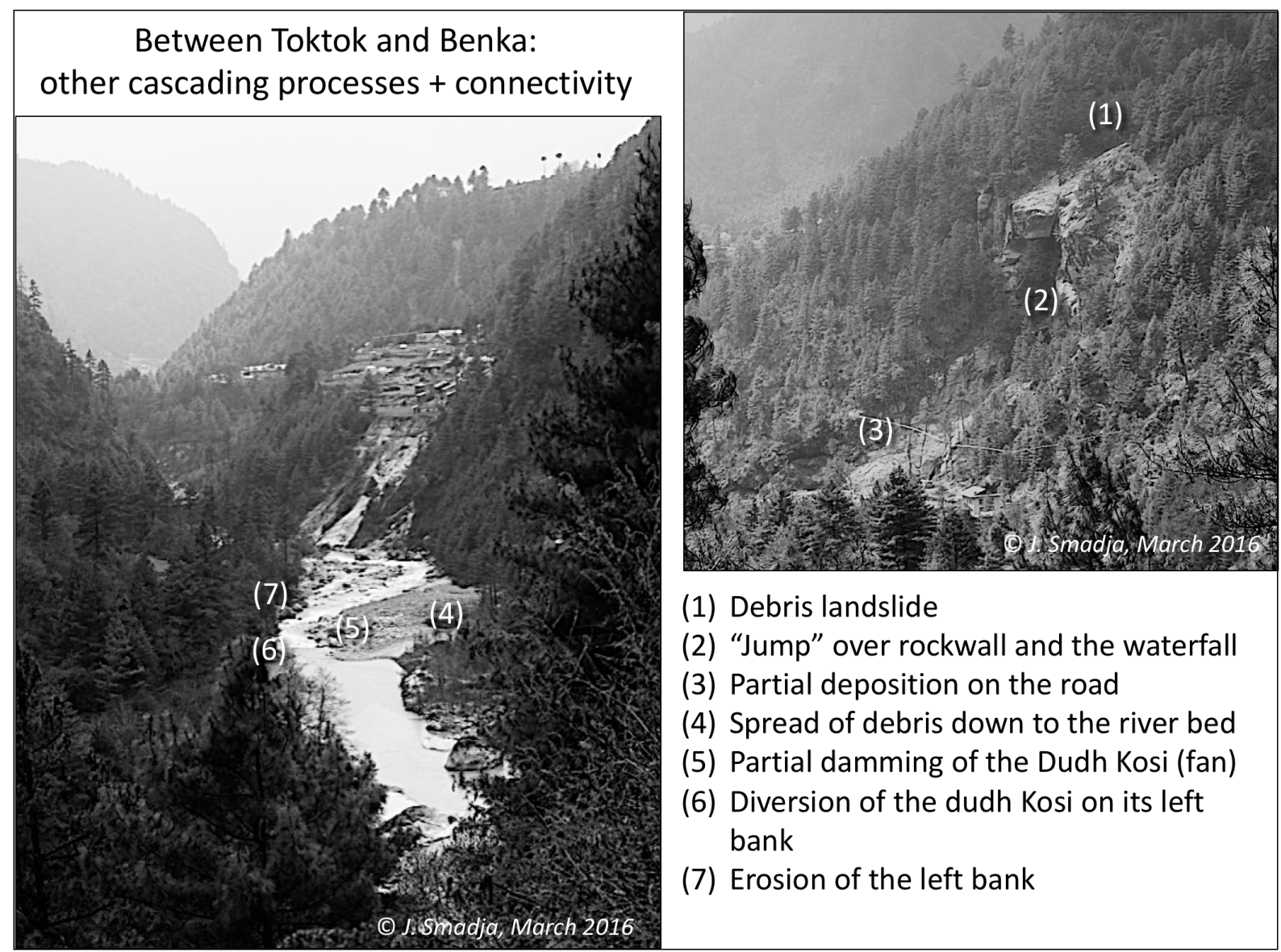

Fig. 8: Series of cascading processes between Tok Tok and Benkar villages, revealing effective hillslope-channel connectivity along the right bank of the Dudh Koshi River. Succession of processes triggered from the upper slope (right photo) down to the channel (left photo). Downhill view, from the trail descending from Benkar village (Photos: () J. Smadja, 2016).

Several sites were observed, two of which were of particular interest.

The first site is located between Tok Tok and Benkar villages (Fig. 8) at a section where the right bank of the Dudh Koshi River is very steep. The site is quite dramatic: the earthquake triggered a debris landslide (middle part of the slope), the material of which "jumped" over a rockwall and the related waterfalls, resulting in a debris flow that was partially deposited on the major Lukla-Namche trail. Yet the volume of debris was such that it extended down to the riverbed, forming a large fan that nearly dammed the Dudh Koshi River, causing the flow of the river to be diverted on its opposite (left) bank, leading to bank undercutting (Fig. 9a). Three years on (Dec. 2018), the debris fan has gradually been revegetated, but relicts of the "damming" episode can still be observed through uncommon white sands still present in the riverbed, reflecting the quiet waters and deposition of suspended sediment by decantation (Fig. 9b).

The second site is located west of the Bupsa village (Kharikhola VDC) and close to the top of the ridge. In March
2015 a landslide pre-existed on the southern slope of the village, together with an incipient gully ( $<2 \mathrm{~m}$ deep) cut across the cultivated terraces downhill of the landslide (Fig. 10). Following the 12th May earthquake, the upslope section of the landslide crown expanded, as expressed by crescentic tension cracks and small fresh scarps, observations confirmed by inhabitants. Then, during that year's monsoon, running waters deeply eroded $(>6$ m) the incipient gully across cultivated terraces: the eroded debris was carried directly downhill, and then fanned out at the junction leading to the Khari Khola where it damaged the new Khari Khola power plant.

\section{Damage to buildings and infrastructures}

The impact of earthquakes on buildings, trails and existing infrastructures (canals, hydropower plants, trails) was also investigated (Fort et al., 2017), and interviews of inhabitants and surveys of their house $(n=150)$ were carried out.

External structural walls of older traditional buildings were affected by cracks originating from the corners of windows and of door jambs ("X-cracking") since they are made of uncut 


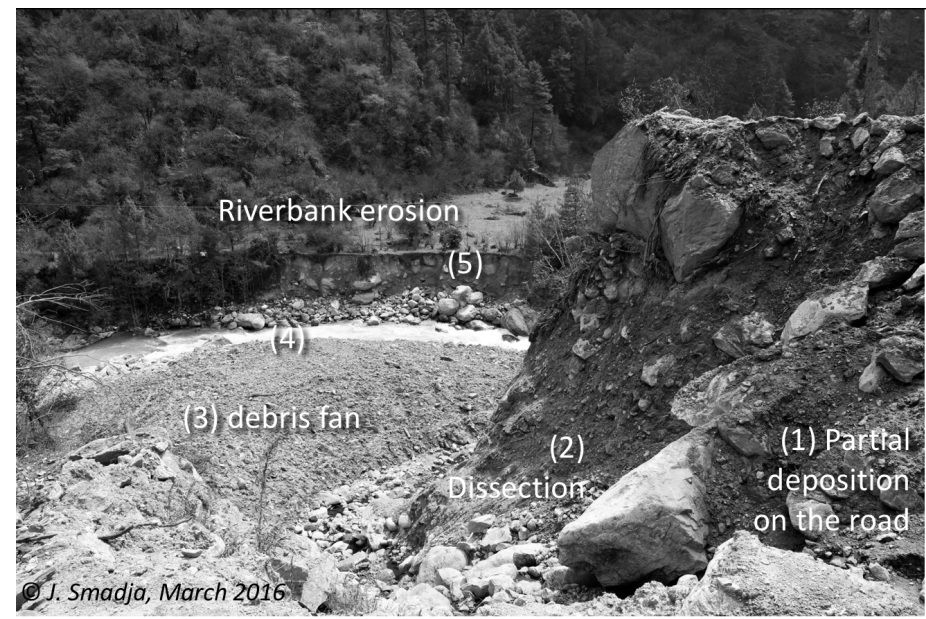

(1) Partial deposition on the road

(2) Dissection and spread of debris down to the river bed

(3) Partial damming of the Dudh Kosi (debris fan)

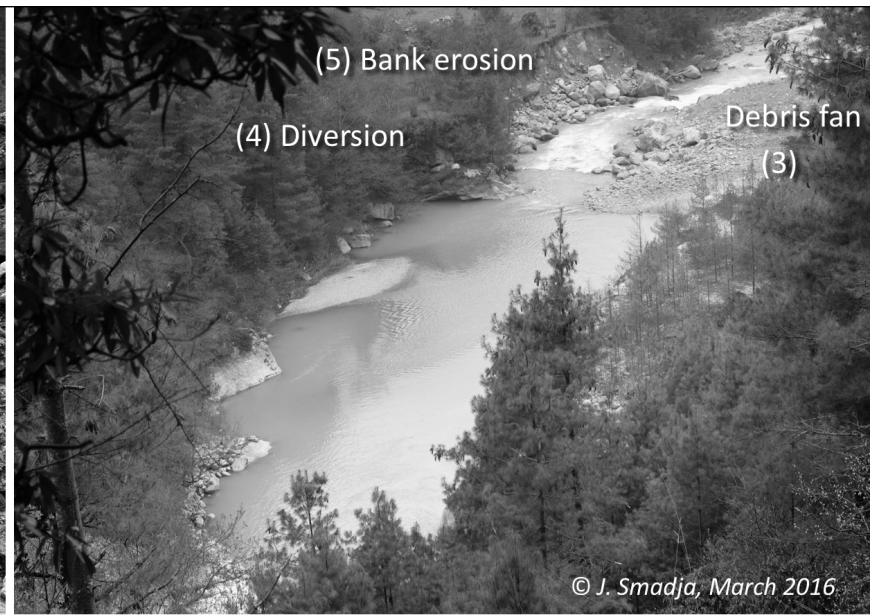

(4) Diversion of the Dudh Kosi on its left bank

(5) Erosion of the left bank

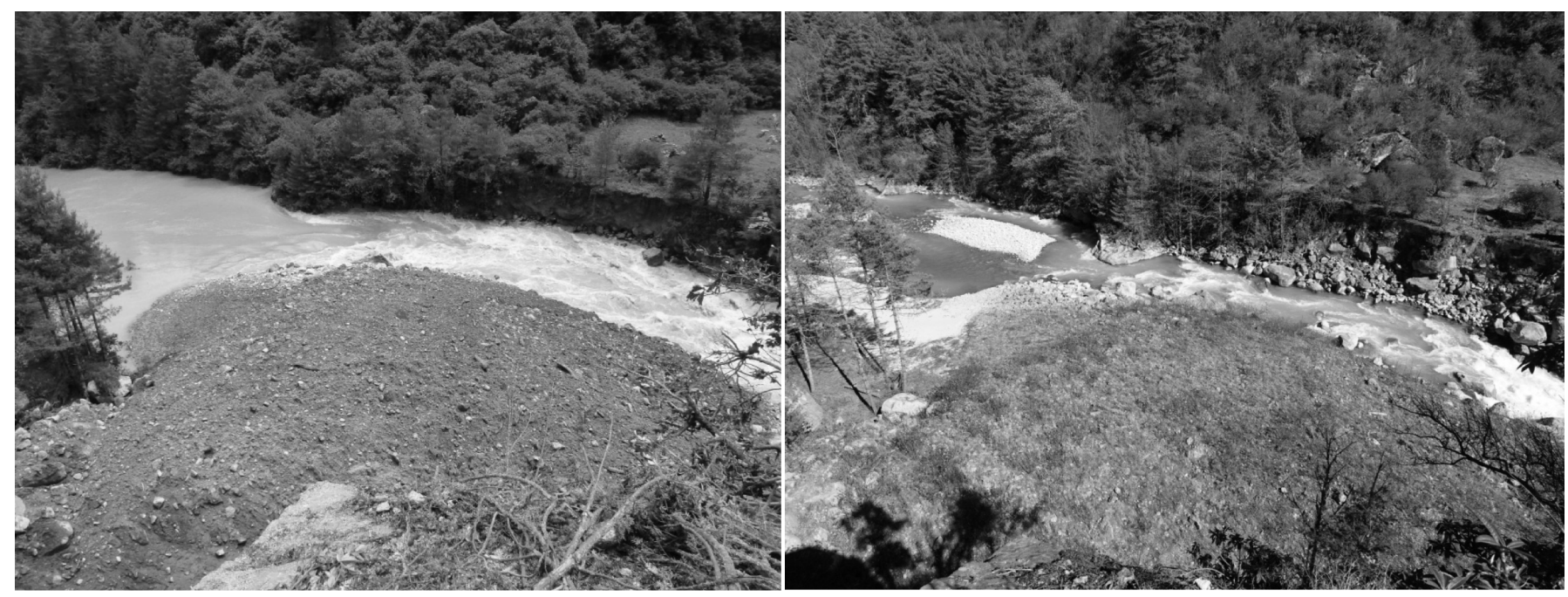

Fig. 9: (a) Focus on the junction between Tok Tok gully and the Dudh Koshi channel (see Fig. 8 for the general context). Note the change in river width, with partial damming of the Dudh Koshi upstream of the debris fan (note the quiet waters), and the resulting erosion of the left bank downstream (fresh section with large boulders) together with the narrow active channel (Photos: (C) J. Smadja), and (b) Comparison between spring 2016 and December 2018 shows rapid re-vegetation of the junction fan, whereas the accumulation of white sand deposited in the Dudh Koshi channel testifies to former river blockage (Photos: (C) B.R. Shrestha, 2016 and M. Fort, 2018).

"field stone" with no mortar or external plaster, just small stones placed between larger stone blocks to fill gaps (Lageson et al., 2016). Other buildings with inside wood panelling, were mostly affected by failure at the top of external rock walls (unreinforced masonry), leaving relatively intact the inside part (Lageson et al., 2016), which explains the very few fatalities (Fig.11). Recent houses with longitudinal and transverse bonding did indeed resisted better, as also observed closer to the Gorkha area (Parajuli and Kiyono, 2015).

Although the age of buildings and construction quality are obvious parameters that go towards explaining the distribution of damaged buildings, other parameters such as the nature and depth of colluvium combined with slope gradient appear to be significant factors that are likely to amplify the effects of ground shaking, as observed in the Khari Khola catchment (Fig. 12) and developed in the Lesser Himalayan series (schists and quartzites). Several houses were damaged in the Khari Khola bazaar, which is built across the axis of an earthflow (loose material) highly susceptible to ground shaking, especially when water-saturated, as during the 12th May aftershock (early spring in this area was quite wet, with unusually abundant rainfall and snowfall). The remaining part of the village extends across the north-oriented hill slopes covered by "colluvium", a mixture 


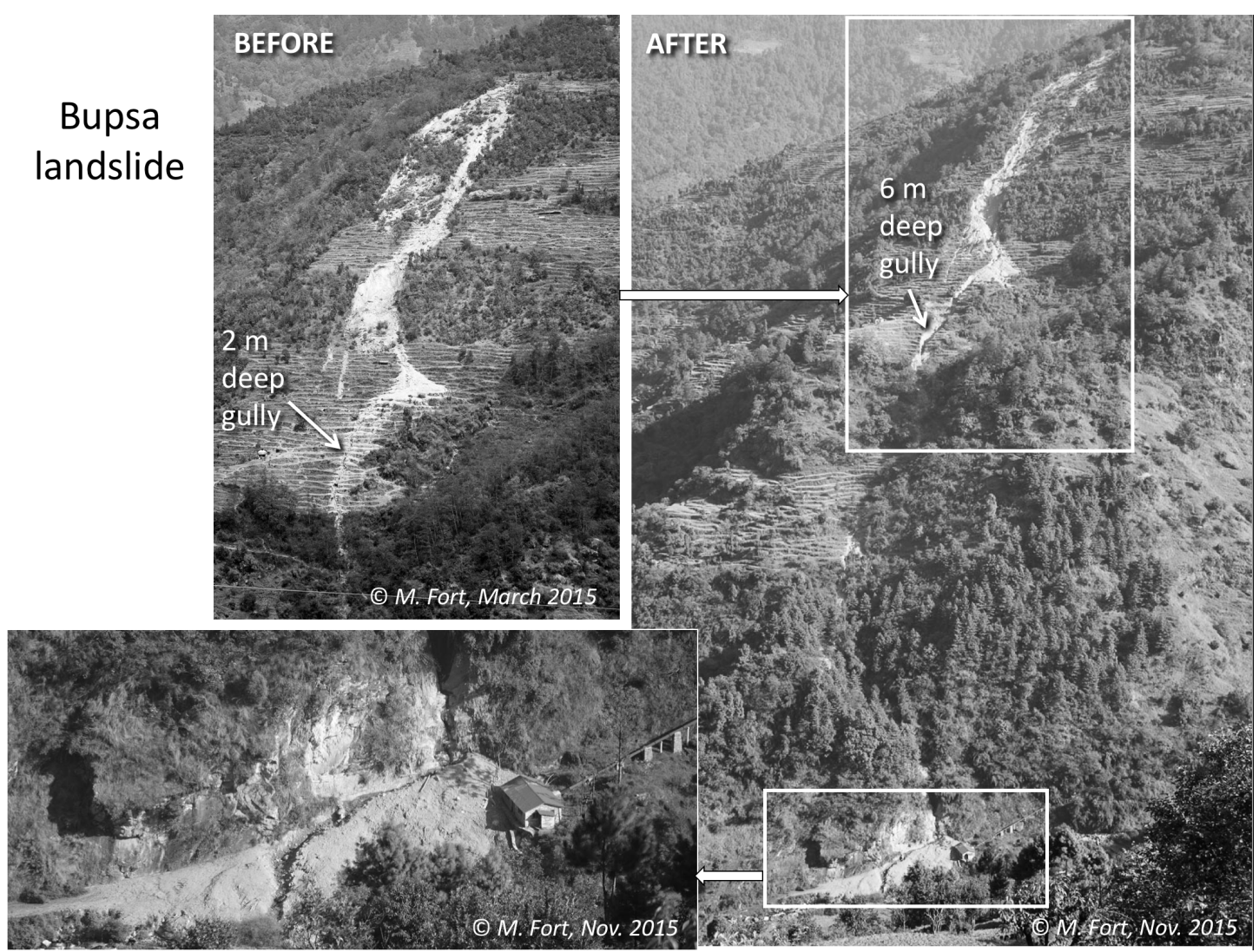

Fig. 10: Cascading processes and impact of the monsoon in Bupsa in 2015. The main gully considerably deepened, and the eroded debris was transported down to Khari Khola junction, hence damaging the new Khari Khola power plant (lower left). (Photos: (C) M. Fort)

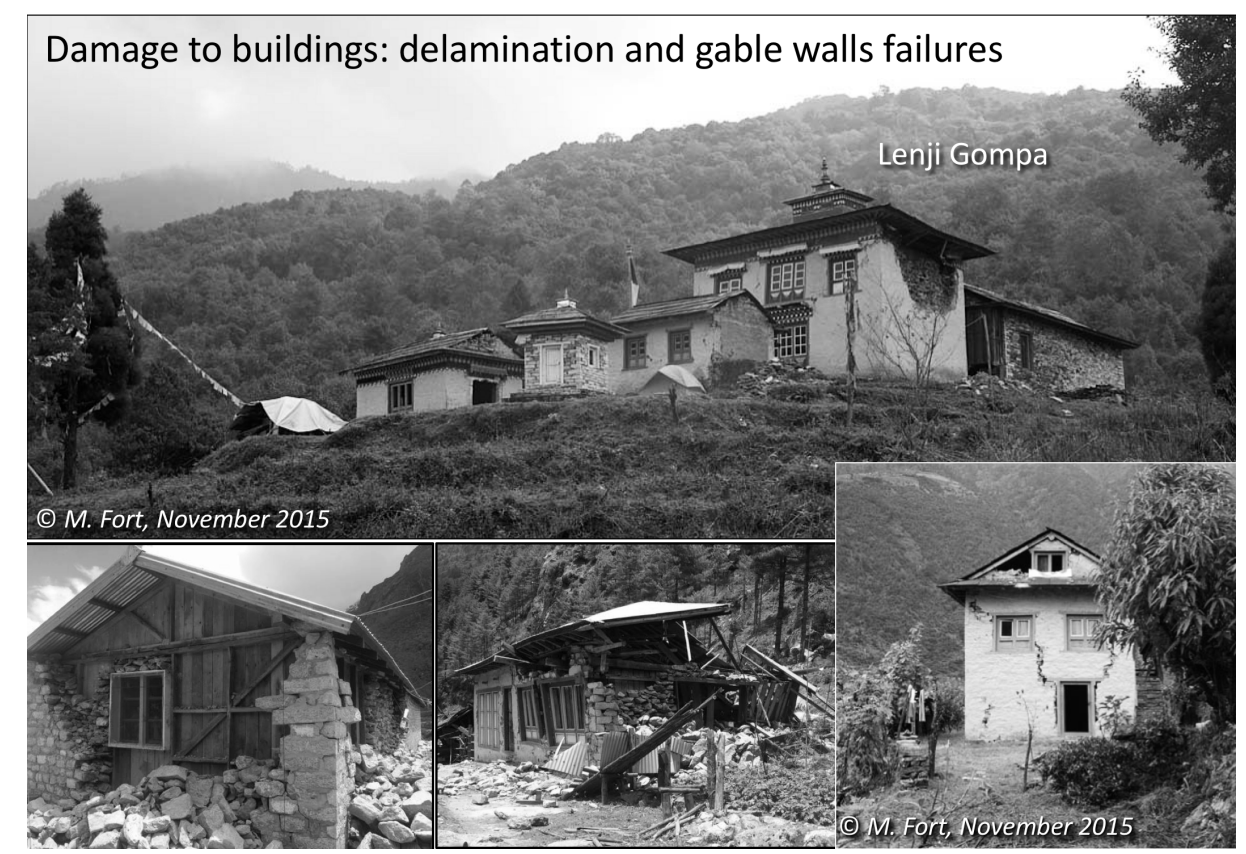

Fig. 11: Significant damage to buildings (Lenji Gompa and houses) in the Khari Khola catchment. "X-cracking" and gable wall failures both due to the type of building and to colluvium soil being susceptible to shaking. (Photos: () M. Fort, November 2015) 


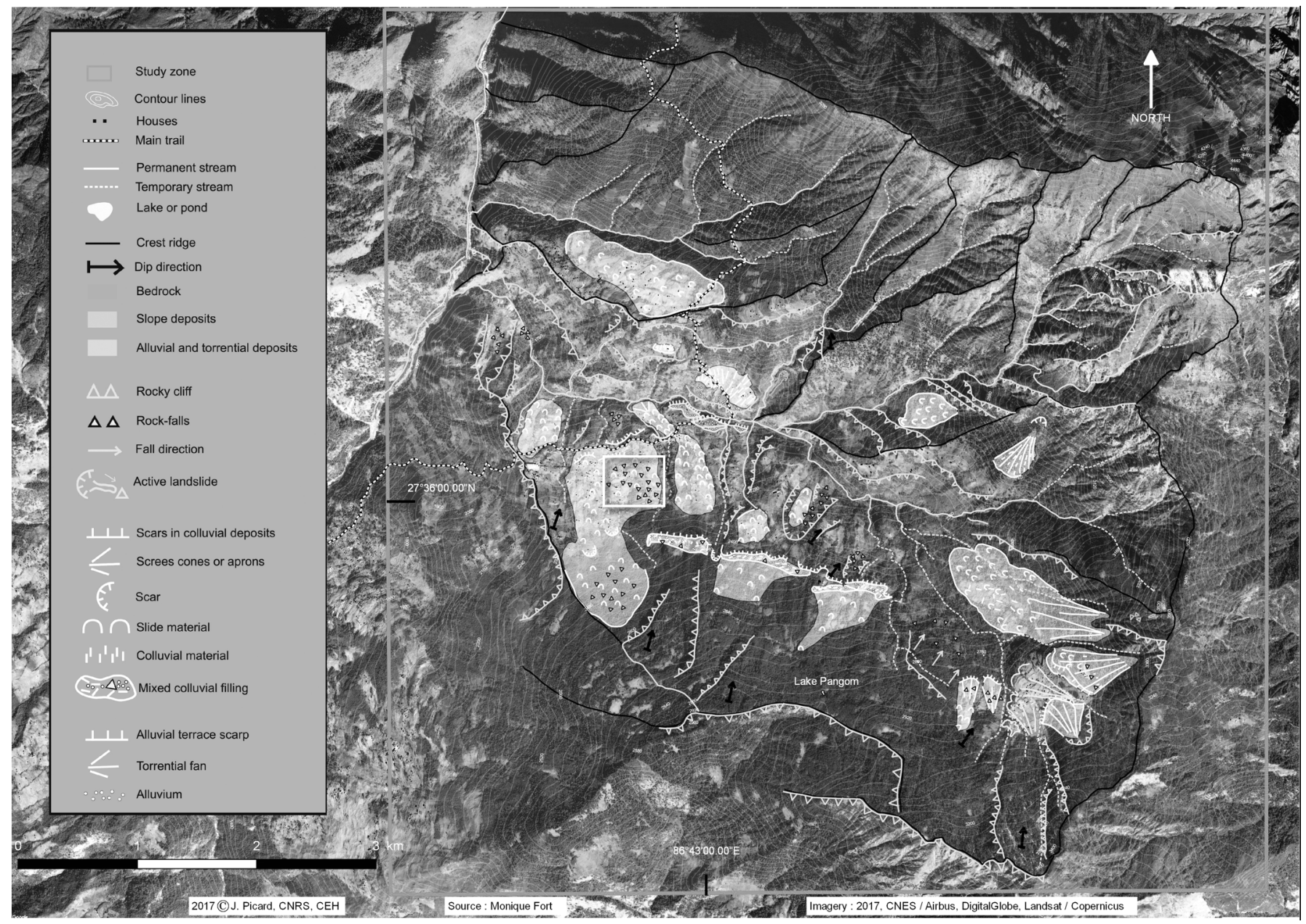

Fig. 12: Geomorphic map of the Khari Khola catchment, showing the importance of slope deposits (colluvium) and their sensitivity to different types of landslides well developed on the southern part of the catchment. The white rectangle (middle part) indicates "Dharyan" blocks (see Fig. 13), whereas immediately to their right colluvium material has been remobilised as an elongated earthflow. (Field mapping M. Fort, (C) final drawing J. Picard)

of fine material (weathered schists) and large blocks. A larger number of damaged houses in the middle of the slope seems to be locally related to a significant concentration of larger blocks $\left(>150 \mathrm{~m}^{3}\right.$ ) that villagers call "Dharyan" (Fig. 13). The notable permeability of these blocks makes them highly susceptible to ground shaking. Following the collapse of the quartzite scarp which dominates the hillslope, we hypothesise that Dharyan might be inherited from, and triggered by, former undated seismic events, though so far we cannot confirm it.

More generally, the destruction of micro hydropower canals (Monjo) by landslides, the erosion of water pipe trenches during the 2015 monsoon, and the burying of water springs (Thulo Gumela, Rato Mato, south of Surke) threatened the water resource, water use and power supply. Adaptations (canal realignment, etc.) were therefore urgently made in order to maintain agricultural and tourism-based livelihood options - a specificity of this area.

\section{DISCUSSION}

Despite the relatively marginal position of Solukhumbu, our observations are similar to those carried in the most centrally earthquake-affected areas in Nepal (Collins and Jibson, 2015; Kargel et al., 2015; Gnyawali et al., 2016; Valagussa et al., 2016). As mentioned above, the limited size and shallow depth of newly generated slope failures are of note in comparison with what is commonly observed after severe monsoon rainfall. Landslide distribution indicates three significant control factors. (i) The lithology: the weak fractured bedrock (schists of the Lesser Himalaya and highly foliated MCT zone) caused rock falls and rockslides, whereas superficial deposits (alluvial, lacustrine, and colluvial soils, including giant debris slides) favoured larger debris-slide failures such as observed south of Monjo, near Ghat, and around Kharikhola. (ii) Slope convexities, steepness $\left(>45^{\circ}\right)$ and height (500-1,000 m) favoured landslide initiation near the top of ridges (Lageson et al., 2016; Roback 


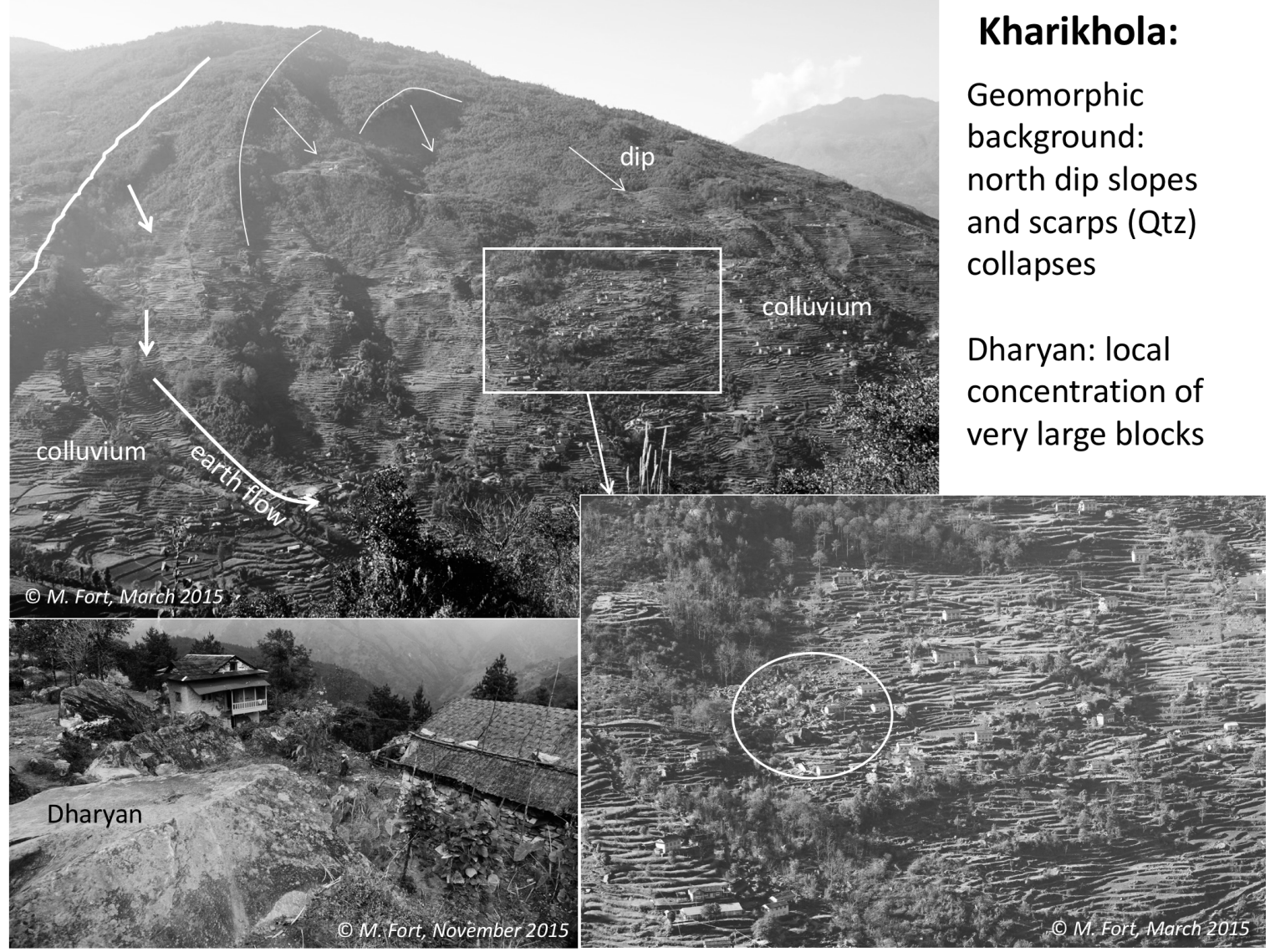

Fig. 13: Geomorphic context of the Khari Khola village, a north-oriented slope with colluvium cover on its lower part, locally reworked as debris flows. "Dharyan", local concentration of large blocks collapsed from quartzitic scarps (cf. dip

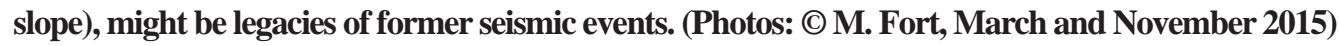

et al., 2018), whereas a series of cascading processes ensured the transfer of debris downhill, locally resulting in temporary damming of the valley (Tok Tok, Bupsa). (iii) The vicinity of deeply incised streams and of the Dudh Koshi River increased the volume of collapsed material, and all the more so because of the presence of terraces of unconsolidated gravel and sand (Nakchung), resulting in the destruction of farmland. Collectively, landsliding was an effective process of directly supplying coarse debris, hence bedload, to rivers in a connectivity chain that was amplified by the 2015 monsoon, as also noted elsewhere by Cook et al. (2016) and Roback et al. (2018).

We are also led to believe that newly generated slope failures and their characteristics may be explained by the specificity of the meteorology of 2015. While the 2014-2015 winter was unusually dry, snowfall and rainfall were abundant during March and April 2015, hence they increased pore pressure and the potential instability of slopes and/or snow cover during the earthquake sequence (Fort, 2016). Conversely, the rather modest monsoon rainfall of the 2015 summer did not take advantage of the many cracks opened by seismic shaking (e.g. Bupsa slope), though it was abundant enough to activate cascading processes.
Another specificity of this area is its proximity with the highest glaciated peaks of Khumbu. We found that the highest density of landslides was to be found close to the Dudh Koshi River channel: there, the most affected areas were those initially damaged by the 1985 Dig Tsho GLOF event (Vuichard and Zimmermann, 1987). More generally, the Gorkha earthquake sequence appears to be one of several other natural disasters that may have affected all the Himalayan valleys, such as GLOFs (Khanal et al., 2015), as also pointed out by Cook et al. (2018) in their study of the Bhote Koshi/Sun Koshi valley after the July 2016 GLOF of Gongbatongshacuo Lake. In Solukhumbu, the newly refreshed outcrops may provide good opportunities for improving our knowledge of Quaternary geology and geomorphic evolution of the last thousand years.

Finally, and in contrast to the most affected, rural, remote areas of central Nepal, the specificity of the tourism-oriented economy of Solukhumbu and Khumbu explains why some buildings (private properties, shops, lodges for tourists, religious buildings) remained in a relatively safe state (better quality and newer buildings), even though many repairs and/or much rebuilding proved necessary and were done rapidly to be able to cater for visitors to the region. 


\section{CONCLUSIONS}

Despite its marginal location, the Solukhumbu area presents similar characteristics to those recognised in central Nepal, the areas most affected by the Gorkha 2015 earthquake sequence. Although shallow, earthquake-triggered landslides caused a significant removal of debris along the steep slopes and major damage to trails, whereas cascading processes following the earthquake crisis and during that year's monsoon reinforced the slope-channel connectivity, hence bedload supply to main streams. The geomorphological setting and the abundance of late quaternary deposits offer higher susceptibility to ground shaking, locally explaining the damage to buildings and infrastructures. Besides, the legacy of former geomorphic disasters, like the 1985 GLOF, reinforces sensitivity to collapse of the steep terrace edges bounding the Dudh Koshi River. One point has not yet been addressed: are the "Dharyan" blocks observed in Kharikhola legacies of former undated seismic events? This question needs to be answered.

\section{ACKNOWLEDGEMENTS}

This work was carried out with funding from ANR-13SENV-0005-02 PRESHINE. We thank the Centre d'études himalayennes (CNRS-CEH), France, and the Department of Geography, Tribhuvan University (Kirtipur Campus), Nepal, for their never-ending support. Warm thanks go to J. Picard $(\mathrm{CEH})$ who helped to finalise some of the illustrations. We are most grateful to D. Lageson, A. Muller and C. Obadia who granted us permission to reproduce their photographs. Bernadette Sellers (CEH) helped with the editorial handling. Our thanks also go to anonymous reviewers who provided useful comments.

\section{REFERENCES}

Carosi, R., Lombardo, B., Musumeci, G., and Pertusati, P., 1999, Geology of the Higher Himalayan crystallines in Khumbu Himal (Eastern Nepal), Journal of Asian Earth Sciences, v. 17 , pp. $785-803$.

Collins, B.D., and Jibson, R.W., 2010, Assessment of existing and potential landslide hazards resulting from the April 25, 2015 Gorkha, Nepal earthquake sequence. US Geological Survey Open-File Report 2015-1142, Reston, VA 2015.

Cook, K., Andermann, C., Adhikari, B.R., and Gimbert, F., 2016, Landslides from the 2015 Gorkha Earthquake in the Bhote Koshi River valley - post-earthquake modification and implications for sediment export. Abstract volume Eighth Nepal Geological Congress (Nov. 27-29, 2016), Kathmandu, Nepal. J. Nepal Geol. Society, v. 52, Sp. Issue, $19 \mathrm{p}$.

Cook, K., Andermann, C., Gimbert F., Adhikari, B.R., and Hovius, N., 2018, Glacial lake outburst floods as drivers of fluvial erosion in the Himalaya. Science Report, 362, 53-57. DOI: 10.1126/science.aat4981
Fort, M., 2004, Quaternary glaciation in the Nepal Himalaya. In: J. Ehlers, and P.L. Gibbard, (eds), Quaternary glaciations - Extent and chronology. Part III: South America, Asia, Africa, Australia, Antarctica. Developments in Quaternary Science, v. 2c, Amsterdam, Elsevier, pp. 261-278.

Fort, M., 2016, Geomorphic changes induced by the April-May 2015 earthquake sequence in the Pharak-Khumbu area (Nepal): preliminary assessments. Geophysical Research Abstracts, Vol. 18, EGU2016-2695.

Fort, M., Khanal, N.R., Shrestha, B.R., and Smadja, J., 2017. Geomorphological disturbance and damage resulting from the April-May 2015 earthquake sequence in Solukhumbu District (Nepal). Journal of Nepal Geological Society, vol. 54, Special Issue, abstract volume of the 11th Asian Regional Conference of IAEG (Nov. 28-30, 2017), 68p.

Gnyawali, K.R., Maka, S., Adhikari, B. R., Chamlagain, D., Duwal, S., and Dhungana, A.R., 2016, Spatial Implications of Earthquake Induced Landslides Triggered by the April 25 Gorkha Earthquake Mw 7.8: Preliminary Analysis and Findings. Intern. Conf. on Earthquake Engineering and Post Disaster Reconstruction Planning, 24-26 April 2016, Bhaktapur, Nepal. Proc. Volume, pp. 50-58.

Goetz, J., Weidinger, J.T., Kraxberger, S., Hennecke, A.L., Buckel, J., and Adhikari, B.R., 2015, Geomorphologic and Hydrogeologic Characteristics of Populated Rockslide Deposits (Sagarmatha National Park, Khumbu Himal, Nepal). Journal of Water Resource and Protection, 7, pp. 1038-1048. http://dx.doi.org/10.4236/jwarp.2015.713085

Grandin, R., Vallée, M., Satriano, C., Lacassin, R., Klinger, Y., Simoes, M., and Bollinger, L., 2015, Rupture process of the $\mathrm{Mw}=7.92015$ Gorkha earthquake (Nepal): insights into Himalayan megathrust segmentation. Geophys. Res. Lett., v. 42 (20), pp. 8373-8382.

Heuberger, H., and Weingartner, H., 1985, Die Ausdehnung de Letzteiszeitlichen Vergletscherung in Ost-Nepal. Zeitschrift für Gletscherkunde und Glazialgeologie, v. 3 (3), pp. 349-364.

Kargel, J. S., Leonard, G. J., Shugar, D. H., Haritashya, U. K., Bevington, A., Fielding, E. J., and Young, N., 2015, Geomorphic and geologic controls of geohazards induced by Nepal's 2015 Gorkha earthquake. Science, June, 1-18. http://doi.org/10.1126/science.aac8353

Lageson, D.R., Fort, M., Bhattarai, R.R., and Hubbard, M., 2016, Damage from the April-May 2015 Gorkha earthquake sequence in the Solukhumbu District (Everest region), Nepal. Geol. Soc. of America Annual Meeting, Denver (Co), Abstracts with Programs. v. 48, No. 7. DOI: 10.1130/abs/2016AM-282306

Parajuli, R.R. and Kiyono, J., 2015, Ground Motion Characteristics of the 2015 Gorkha Earthquake, Survey of Damage to Stone Masonry Structures and Structural Field Tests, Frontiers in Built Environment 1(23), DOI: 10.3389/fbuil.2015.00023 
Posch, E., Bell, R., Weidinger, J.T., and Glade, T., 2015, Geomorphic Processes, Rock Quality and Solid Waste Management-Examples from the Mt. Everest Region of Nepal. J. of Water Resource and Protection, v. 7, pp. 1291-1308.

Roback, K., Clark, M.K., West, A.J., Zekkos, D., Li, G., Gallen, S.F., Chamlagain, D., and Godt J.W., 2018, The size, distribution, and mobility of landslides caused by the 2015 Mw7.8 Gorkha earthquake, Nepal. Geomorphology, v. 301, pp. 121-138.

http://dx.doi.org/10.1016/j.geomorph.2017.01.030

Schelling, D., 1999, Geological Map of the eastern Nepal Himalaya (scale 1:650,000), in P. Le Fort and B.N. Upreti (eds.), Geology of the Nepal Himalayas: Recent Advances. Journal of Asian Earth Sciences, v. 17, pp. 577-606.

Shrestha, A.B., Bajracharya, S.R., Kargel, J.S., and Khanal, N.R., 2016, The impact of Nepal's 2015 Gorkha earthquake-induced geohazards. ICIMOD Research Report 2016/1. Kathmandu, ICIMOD.

Shrestha, B.R., 2017, Geo-hydrological Hazards induced by Gorkha Earthquake 2015: Everest Region, Nepal. M.Sc. Thesis, Central Department of Geography, Tribhuvan University, Kirtipur, Kathmandu, Nepal. 102p.

Smadja, J., Aubriot, O., Puschiasis, O., Duplan, T., Grimaldi,
J., Hugonnet, M., and Buchheit, P., 2015, Climate change and water resources in the Himalayas. Journal of Alpine Research | Revue de géographie alpine [online], 103-2 |, URL: http://journals.openedition.org/rga/2910; DOI: 10.4000/rga.2910.

Valagussa, A., Frattini, P., Crosta, G.B., Valbuzzi, E., 2016, Pre and post 2015 Nepal earthquake landslide inventories. In: S. Aversa, Cascini L., L. Picarelli, C. Scavia (Eds), Landslides and Engineered slopes. Experience, Theory and Practice. Proc. of the 12th Intern. Symposium on Landslides (Naples, Italy, 12-19 June 2016). CRC Press 2016. pp. 1957-1964. Ch. 234.

Vuichard, D. and Zimmermann, M., 1987, The 1985 catastrophic drainage of a moraine-dammed lake, Khumbu Himal, Nepal. Causes and consequence, Mountain Research and Development, 7, pp. 91-110.

Weidinger, J.T., Korup, O., Munack, H., Altenberger, U., Dunning, S., Tippelt, G. and Lottermoser, W., 2014, Giant Rockslides from the inside. Earth and Planetary Science Letters, 389, pp. 62-73.

Yoshida, M., Upreti, B.N., and Rai, S.M., 2011, Guidebook for Himalayan trekkers, Series no.2. Department of Geology, Tri-Chandra Campus, Tribhuvan University, Kathmandu, Nepal. 192p. 